Original Research Paper

\title{
Chronic and Acute Effect of Tramadol Intoxication on Some Immunological Parameters
}

\author{
${ }^{1}$ Loveday Udu Zebedee, ${ }^{2}$ Zaccheus Awortu Jeremiah, ${ }^{3}$ Nyebuchi Jonathan and ${ }^{4 *}$ Eni-Yimini Solomon Agoro \\ ${ }^{l}$ Department of Haematology and Blood Transfusion, Federal Medical Centre, Yenagoa, Bayelsa State, Nigeria \\ ${ }^{2}$ Department of Medical Laboratory Science, College of Health Science, Niger Delta University, \\ Wilberforce Island, Bayelsa State, Nigeria \\ ${ }^{3}$ Department of Haematology and Blood Transfusion Science, Rivers State University, Port Harcourt, Rivers State, Nigeria \\ ${ }^{4}$ Department of Biochemistry, Faculty of Science, Federal University Otuoke, Bayelsa State, Nigeria
}

\author{
Article history \\ Received: 16-11-2020 \\ Revised: $16-03-2020$ \\ Accepted: 25-03-2020 \\ Corresponding Author: \\ Eni-Yimini Solomon Agoro \\ Department of Biochemistry, \\ Faculty of Science, Federal \\ University Otuoke, Bayelsa \\ State, Nigeria \\ Email: enisagoro@gmail.com
}

\begin{abstract}
Tramadol intoxication is rapidly on the increase in Nigeria with unestablished short-term and long-term effects. The study was aimed at elucidating the dose-dependent effect of acute or chronic tramadol intoxication on some immunological parameters using male rats (Rattus norvegicus). A total of fifty adult rats were used for the study as indicated by Mead's Resource Equation. The study consisted of acute and chronic categories of fifty adult rats randomly pair-divided into groups of six rats each. The acute phase consisted of a control group of 6 rats administered with normal saline solution and a treatment group of 6 rats administered with lethal dose of tramadol. The chronic phase comprised of control group of 6 rats and 3 tramadol-dependent groups of 6 rats each administered orally with 50,100 and $200 \mathrm{mg} / \mathrm{kg}$ of tramadol for a period of 90 days respectively. Student $t$-test, one-way Anova and Pearson correlations were the statistical tools used for the data analysis employing JMP statistical discovery ${ }^{\mathrm{TM}}$ software version 14.1. Blood samples were collected by cardiac puncture for immunological examination using World Health Organization (WHO) approved methods. The study revealed that concentrations $\mathrm{IgG}$, IgM and CD4 were significantly elevated $(p>0.05)$ in the acute treatment group compared with the controls. However, the chronic phase of the study showed a progressive significant increase ( $p>0.05)$ in CD4 count. Conclusively, the study has demonstrated that tramadol intoxication has the preponderances of altering the immune apparatuses of the body.
\end{abstract}

Keywords: Tramadol, Rats, Globulins, CD4, White Cells, Proteins

\section{Introduction}

Tramadol is an opioid pain medication used primarily to treat mild to severe pain, both acute and chronic (Rossi, 2013; Grond and Sablotzki, 2004). When taken by mouth in an immediate-release formulation, the onset of pain relief usually begins within an hour. Deaths due to tramadol overdose have been reported and are increasing in frequency across the globe with recognized risk factors such as depression, addiction and seizures (Randall and Crane, 2014).

Immunological parameters are defense guard used by the body to prevent the floodgate of diseases and toxic conditions. White blood cells are component of full blood count used for measuring the inflammatory and immune status of the body. An elevated or decreased count of white cells and its sub-types are very crucial in assessing the immune status of the body to infection, infestation, cancer and/or toxicity (Agoro et al., 2019).

Another immunological parameter used for assessing immune status is serum globulin concentration and its components. Globulins are proteins that include gamma globulins (antibodies) and a variety of enzymes and carrier/transport proteins. Globulin concentration has been shown as an indicator of immune-derangement (Agoro et al., 2012). Immunoglobulins are family of protein antibodies that occur in five major forms; $\operatorname{IgM}, \operatorname{IgD}, \operatorname{IgG}, \operatorname{IgE}$ and $\operatorname{IgA}$. They are very essential in assessing immune competence of the body. IgM and IgG are front line immune proteins 
used by the body to wade off foreign bodies and microbes (Alberts et al., 2002; Capolunghi et al., 2013; Williams and O'Connell, 2008; Junqueira and Jose, 2003; Lakos et al., 2008; Cox et al., 2008).

Also of importance in assessing the immune competence is CD4 count. Cluster of Differentiation 4 (CD4) is a glycoprotein found on the surface of immune cells such as $\mathrm{T}$ helper cells, monocytes, macrophages and dendritic cells. They form essential part of the human immune system and participate in sending signals to other types of immune cells, including CD8 killer cells, which then destroy infectious particles. If CD4 cells become depleted, for example in untreated HIV infection, or following immune suppression prior to a transplant, the body is left vulnerable to a wide range of infections. Tcells play a crucial role in the containment of autoinflammatory diseases and toxicological poisoning (Ciccarelli et al., 2014).

Tramadol addiction and abuse is a very common phenomenon in the Niger Delta region of Nigeria and other parts of the country (Ibrahim et al., 2017; Chikezie and Ebuenyi, 2019). Tramadol rapidity to pain relief is now heavily patronized outside medical prescription and is now classified as a criminal ecstasy in Nigeria. Due the rampancy and abuse of tramadol, the Federal Government of Nigeria in 2018 banned the importation, production and sale of tramadol (BBC News, 2018). This approach was adopted to curb the geometric leap in crimes which correlated with the abuse drugs such as tramadol.

The immunological status of the body upon exposure to acute or chronic tramadol intoxication or administration is still hazy. Immunological status of the body is the major basis upon which health and life sustenance is maintained. The entire body sustenance is a product of well-coordinated immunological responses. Immunological responses are well regulated as minor alteration could lead to unprecedented release of immune cells and/or immune proteins and molecules. Stimulation of immune cells and molecules could be directed at foreign bodies and at times on self. The effect of tramadol on immunological cells and markers have been studied with a diverging perspectives, though with different study animals and narratives (Sacerdote et al., 2000; Liu et al., 2006; Sacerdote et al., 1997; Hamad et al., 2016). Some of the studies posited that tramadol intoxication has significant effects on some immunological parameters, whereas others are of contrary opinion. Aside the effect of tramadol intoxication on immunological and biochemical parameters, the design of the above studies did not put into cognizance both acute and chronic implications. The discrepancies, intoxication span and divers' perspectives of tramadol intoxication gave birth to this study. to put this narrative in perspective, this study utilized globulin, IgM and $\mathrm{IgG}$ in determining the immune fidelity of the body upon tramadol intoxication. This study is therefore crafted to addressing the role of acute and chronic tramadol intoxication on apparatuses that play crucial roles in keeping the balance of immunological profiles of the body.

\section{Materials and Methods}

\section{Study Area}

The animal breading and inducement were carried out at the Pharmacology Laboratory of the Niger Delta University (NDU), Wilberforce Island, Bayelsa State, Nigeria. Similarly, the laboratory analysis took place at the Haematology and Chemical Pathology Laboratories of the Federal Medical Centre, Yenagoa, Bayelsa State and the Niger Delta University Teaching Hospital, Okolobiri, Bayelsa State respectively. Bayelsa state is located within Latitude 40151 North and Latitude 50 and 231 South, longitude 50221 West and 60451 East (Alagoa, 1999).

\section{Study Population}

The study used Mead's Resource Equation for the sample size determination (Hubrecht and Kirkwood, 2010). The study was categorized into acute and chronic phases. The acute phase was further divided into two groups; controls and tramadol intoxication death. The chronic phase comprised of four groups of different grades of concentrations of tramadol dosages. Each group was made up of five rats paired with an age-matched control. In total fifty rats were used for both the acute and chronic phases of the study. The acute phase was concluded within twenty four hours, whereas the chronic took three months, excluding two weeks of acclimatization. Randomized block experimental research designed was employed for this research.

The experimental component of the study was carried out in three months starting in February to May of 2019. Literature search and write-up took another three months (June to August 2019).

\section{Ethical Approval}

The ethical clearance and experimental protocol was approved by the Ethics Committee of the Bayelsa State Ministry of Health (Ref/2019/0100). The Animal Welfare Act of 1985 of the United States of America for research and Institutional Animal Care and Use Committee (IACUC) protocols were stringently adhered to.

\section{Selection Criteria}

Albino rats used were apparently healthy and active as confirmed and approved by a veterinarian. Rats showing signs and symptoms of illness were excluded from the research. Also excluded were rats with any form of derangements or deformity. The research utilized only male albino rats of same approximate age and weight. The age range was between six to eight months. The weight brackets were 300-320g. Lysed samples were also rejected. 


\section{Collection of Sample}

Blood samples were collected from the heart using the method postulated by (Ness, 1999). The samples were withdrawn slowly into EDTA and plain containers for immunological investigations. The immunological analyses carried out include $\operatorname{IgG}, \operatorname{IgM}$, globulin, albumin and total protein, white blood cell count, white cell differentials and CD4.

\section{Experimental Outcome}

The signs and symptoms for adverse reaction resulting from tramadol intoxication in the various groups were insignificant. The weight differences were also insignificant. Summarily, the rats did not develop any seizures, diarrhea or loss of weight or any significant behavioral changes compared to the control.

\section{Laboratory Procedures}

Serum total protein and albumin concentrations were estimated quantitatively with Biuret and Bromocresol Green (BCG) methods respectively using Randox reagents (United Kingdom). Serum globulin concentrations were derived by subtracting serum albumin from serum total protein (Michael et al., 1991). Serum IgG and IgM concentrations were estimated quantitatively using turbidimetry method as modified by BioSystems (Spain).
Automated analyzer was used for the white cell counts and white cell differentials estimation. Double Positive (DP) flow cytometry was used for CD4 enumeration.

\section{Statistical Analysis}

The immunological data obtained were analyzed using student t-test and One-way Anova. Box-plots were also used for data presentation. JMP statistical discovery ${ }^{\mathrm{TM}}$ software version 14.1 (SAS Institute, Cary, NC, USA) was used for the data analysis. The data were expressed as Mean \pm SEM.

\section{Results}

Table 1 shows comparison of immunological parameters in the acute stage of treatment and control groups. The mean $\mathrm{CD} 4+$ count, serum IgG and IgM were significantly elevated in the treatment group when compared with the control group. Others parameters were not significant. The comparison of immunological parameters in the experimental treatment during the chronic stage is shown in Table 2. It was only CD4+ count that was elevated up to $100 \mathrm{mg} / \mathrm{kg}$ and dropped to nearly the baseline concentration at $200 \mathrm{mg} / \mathrm{kg}$. Tables 3 and 4 show a pairwise correlation of immunological parameters following acute and chronic intoxications of varying concentrations of tramadol respectively.

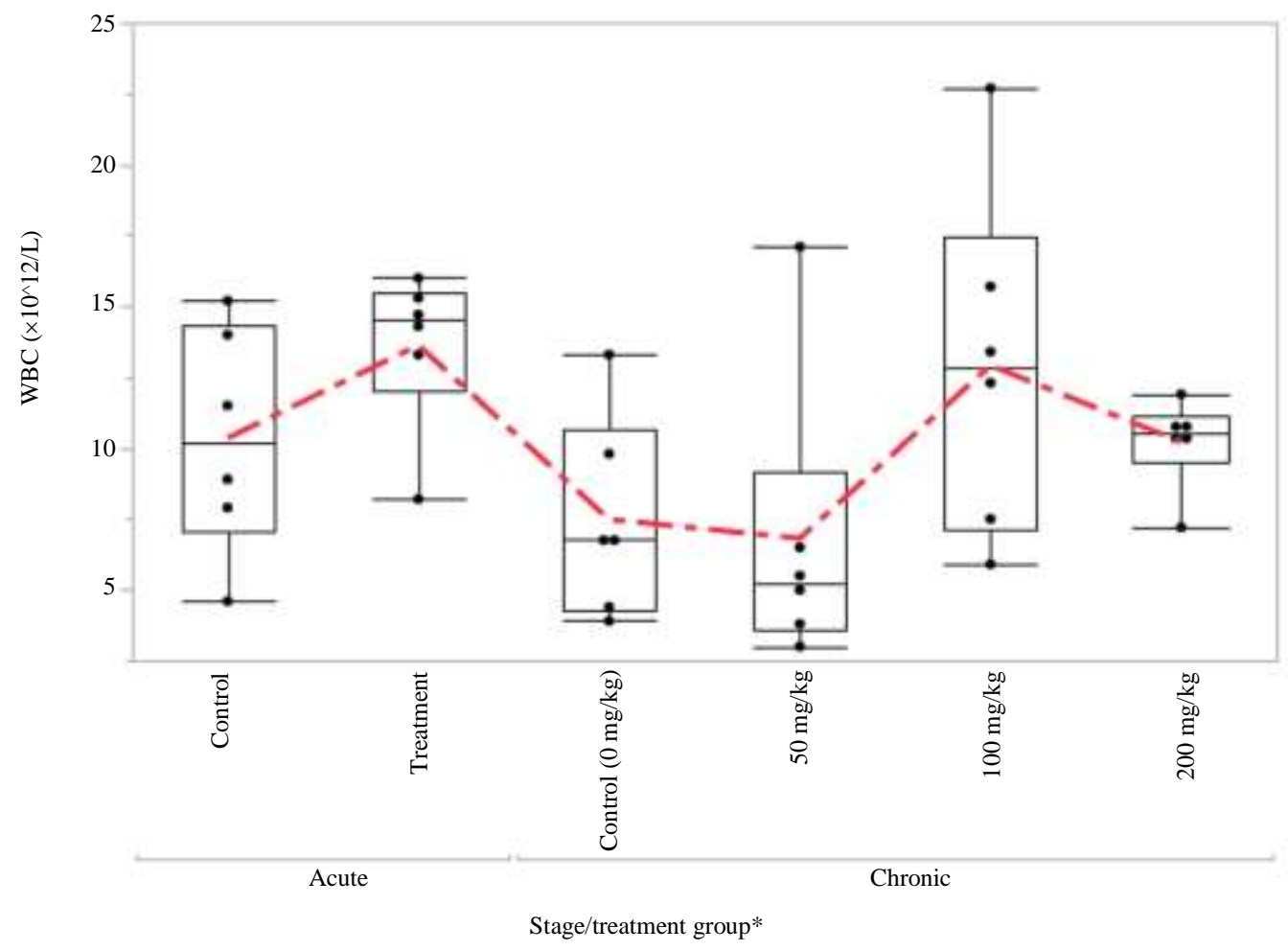

Fig. 1: Box plot of WBC counts in the control and treatment groups during acute and chronic intoxications 


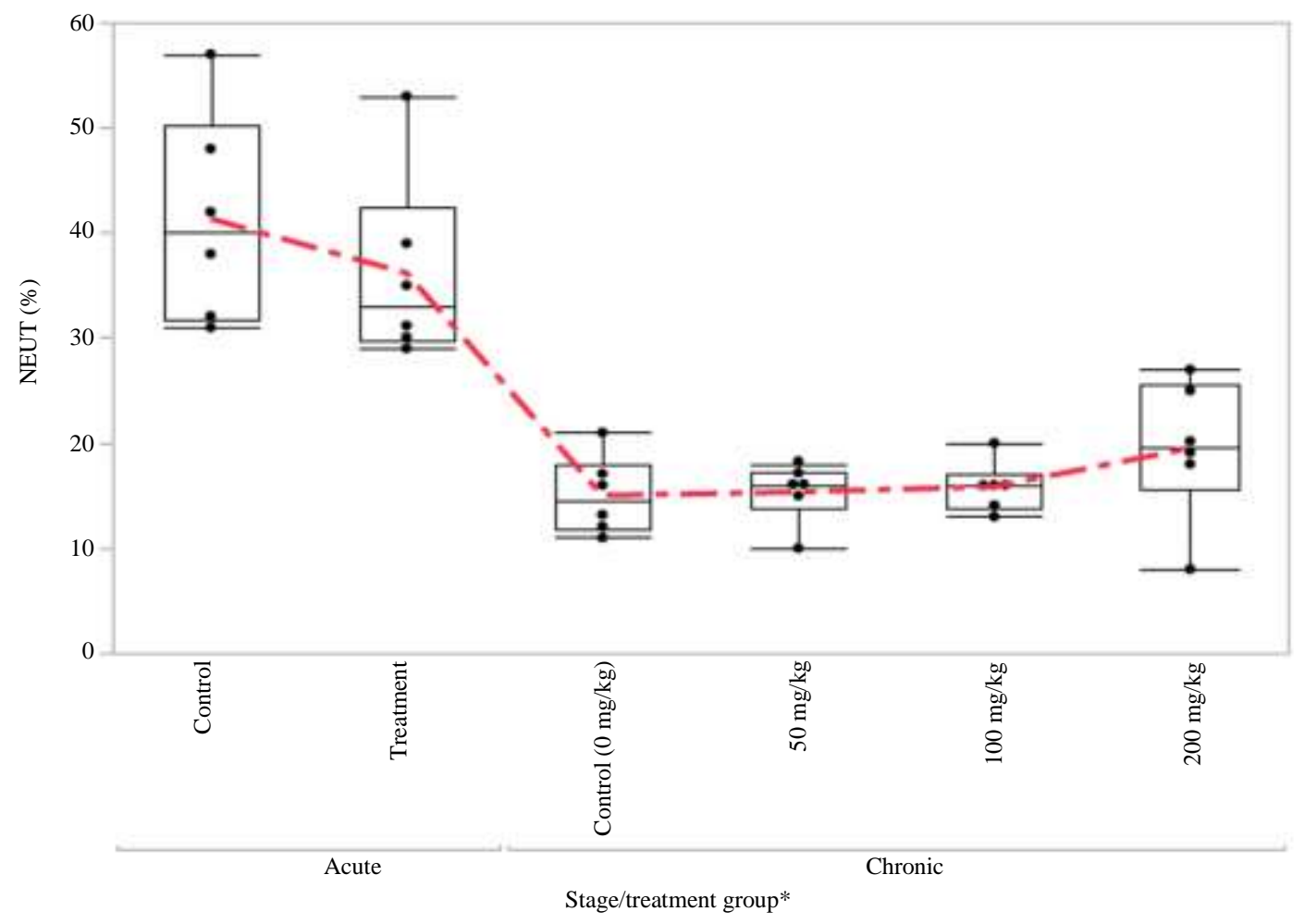

Fig. 2: Box plot of neutrophil counts in the control and treatment groups during acute and chronic intoxications

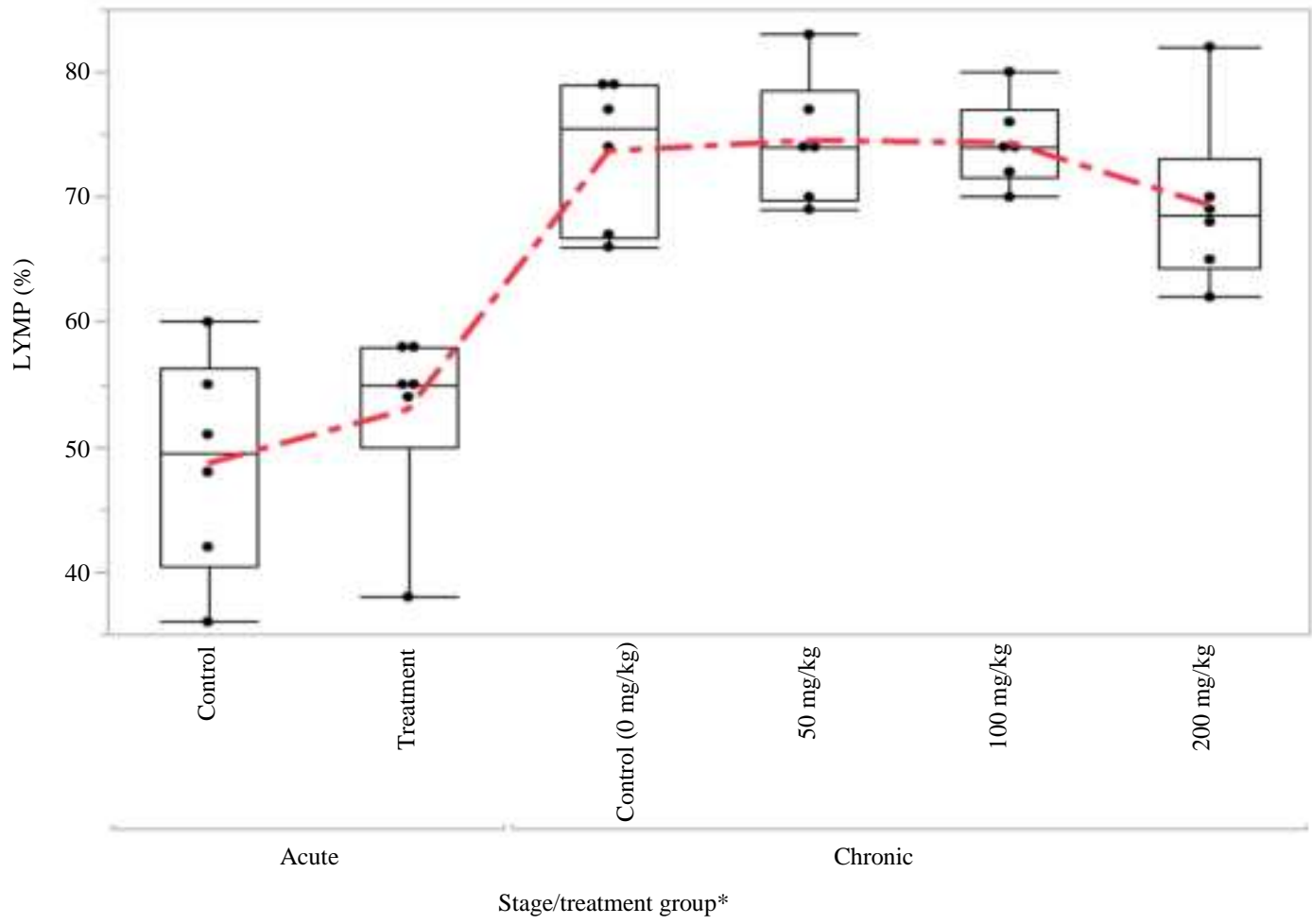

Fig. 3: Box plot of lymphocytes counts in the control and treatment groups during acute and chronic intoxications 


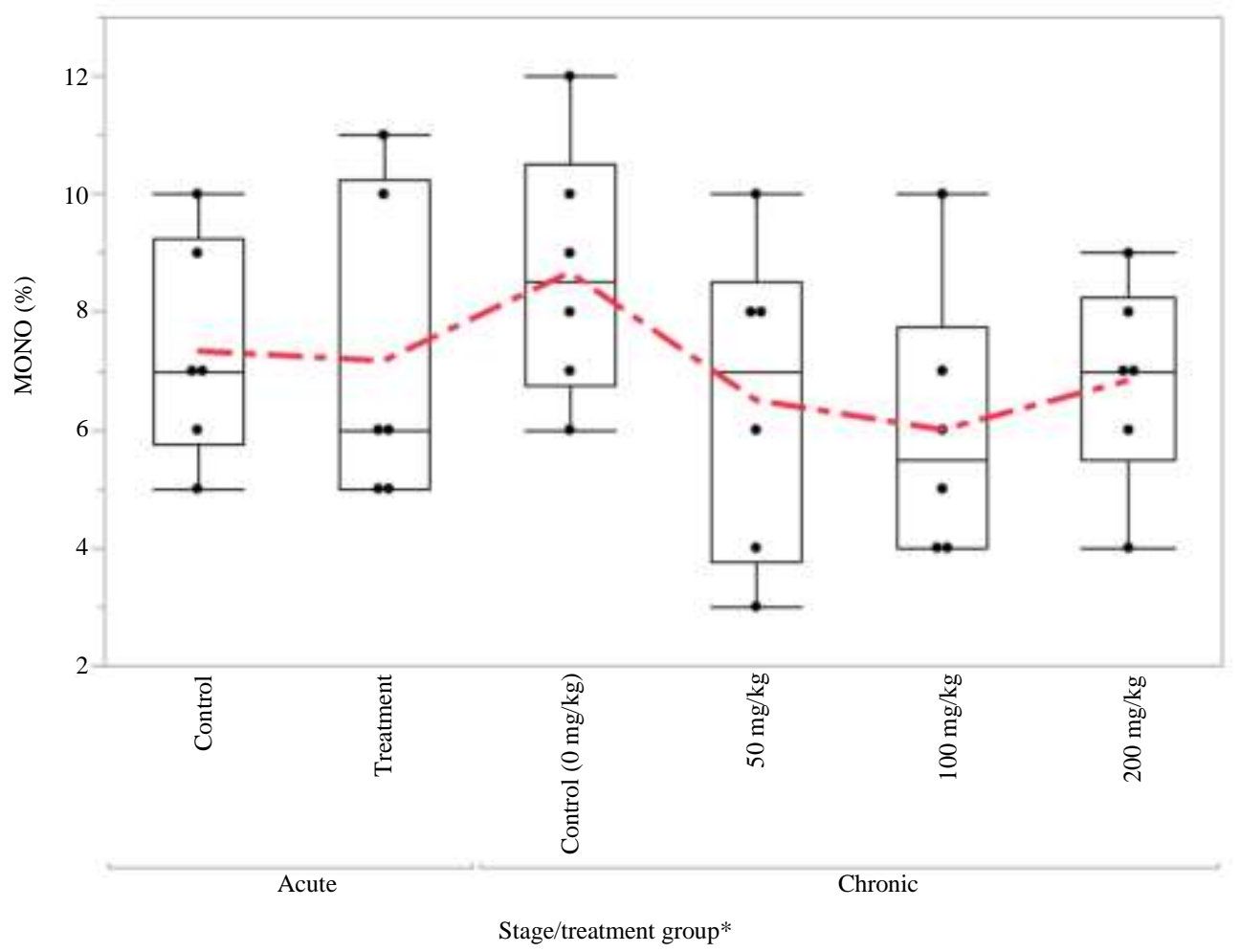

Fig. 4: Box plot of monophil counts in the control and treatment groups during acute and chronic intoxications

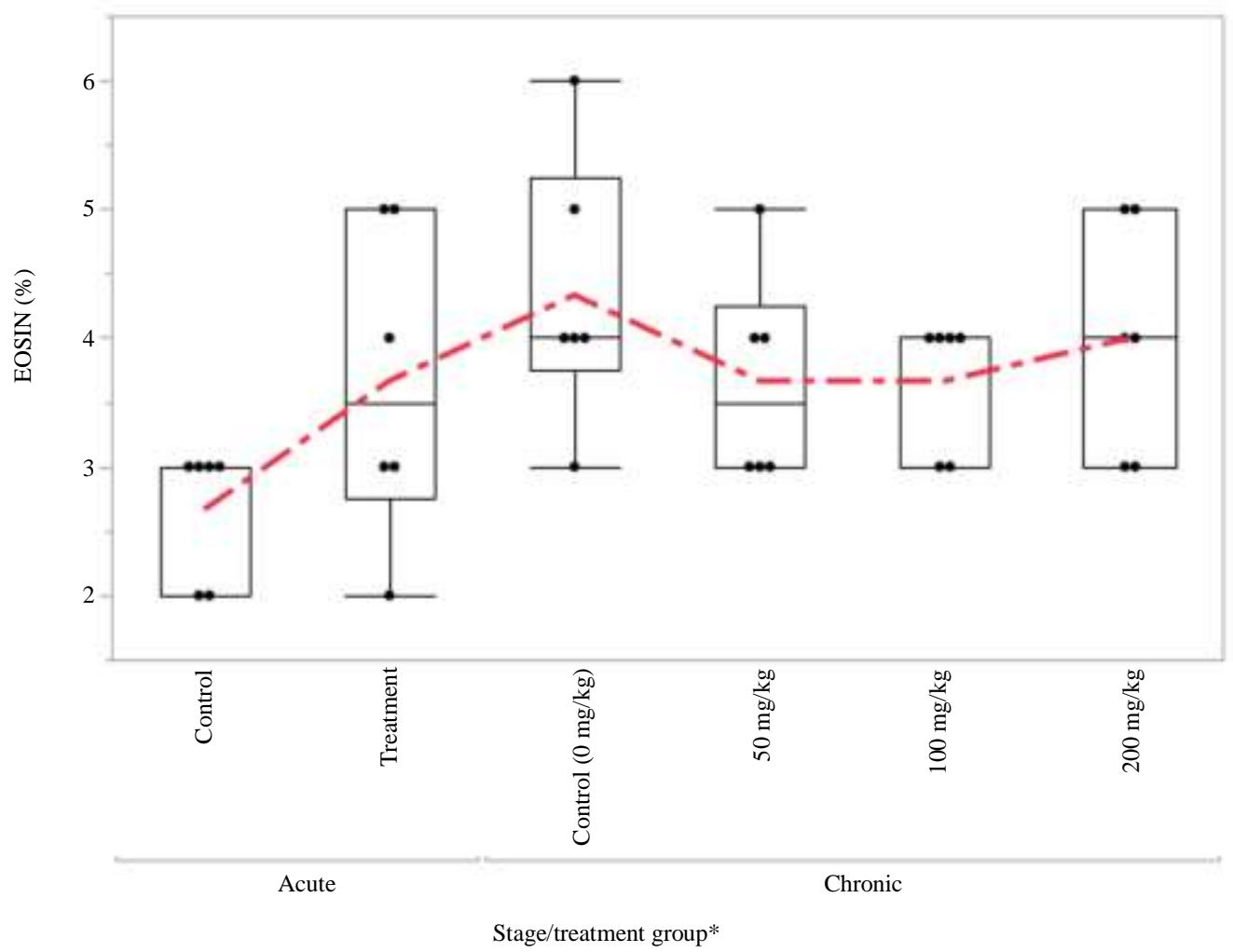

Fig. 5: Box plot of eosinophil counts in the control and treatment groups during acute and chronic intoxications 


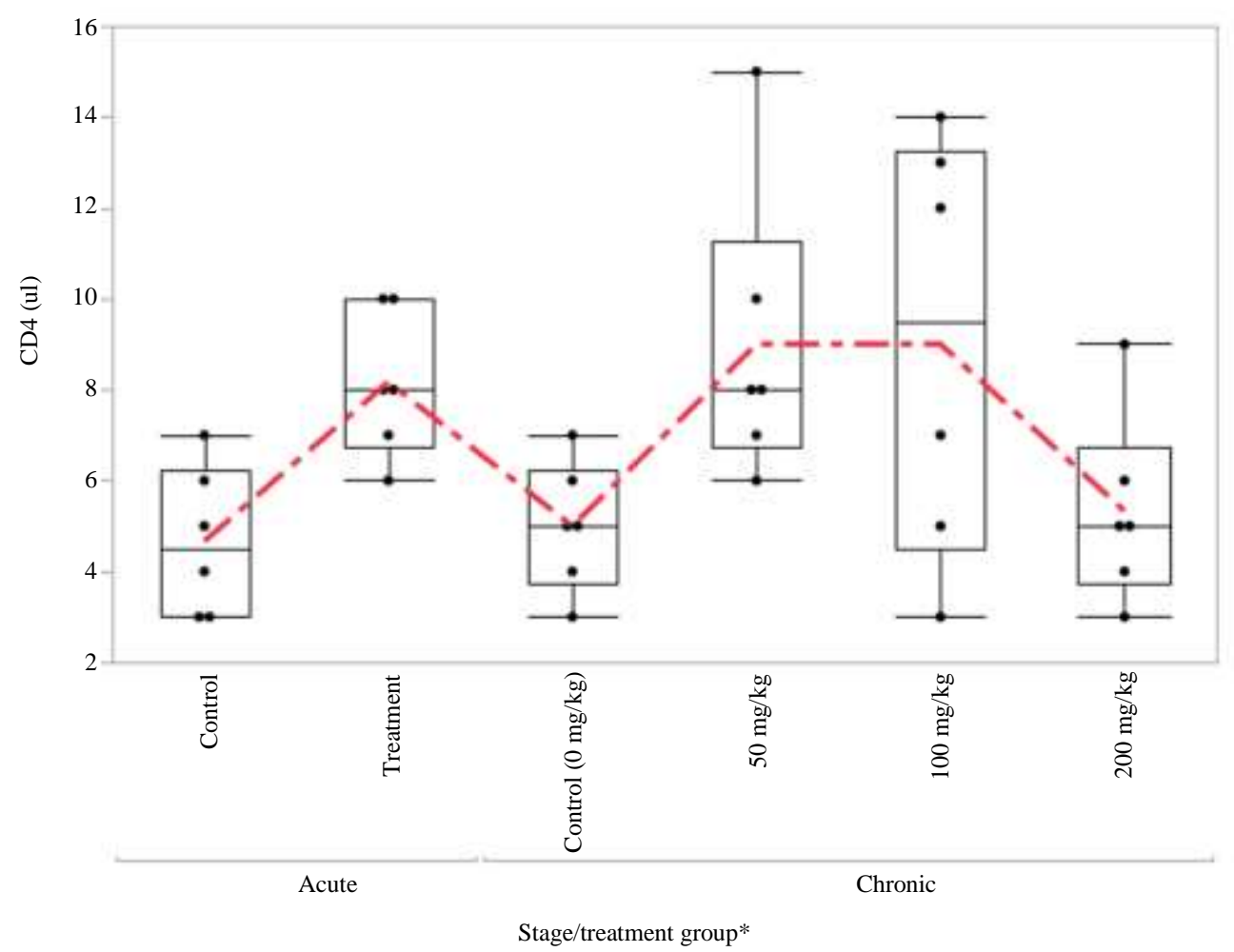

Fig. 6: Box plot of CD4 counts in the control and treatment groups during acute and chronic intoxications

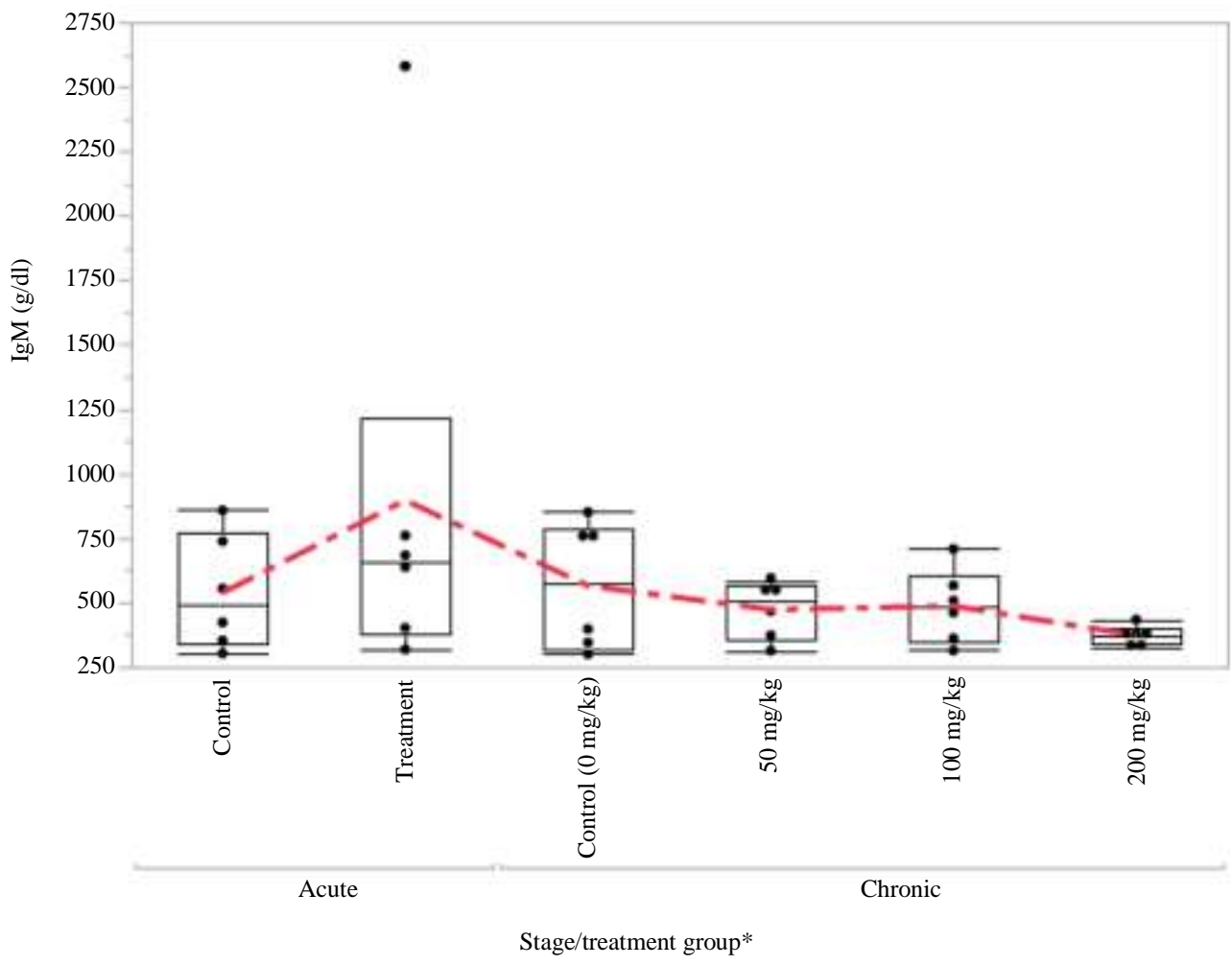

Fig. 7: Box plot of serum $\operatorname{IgM}$ in the control and treatment groups during acute and chronic intoxications 


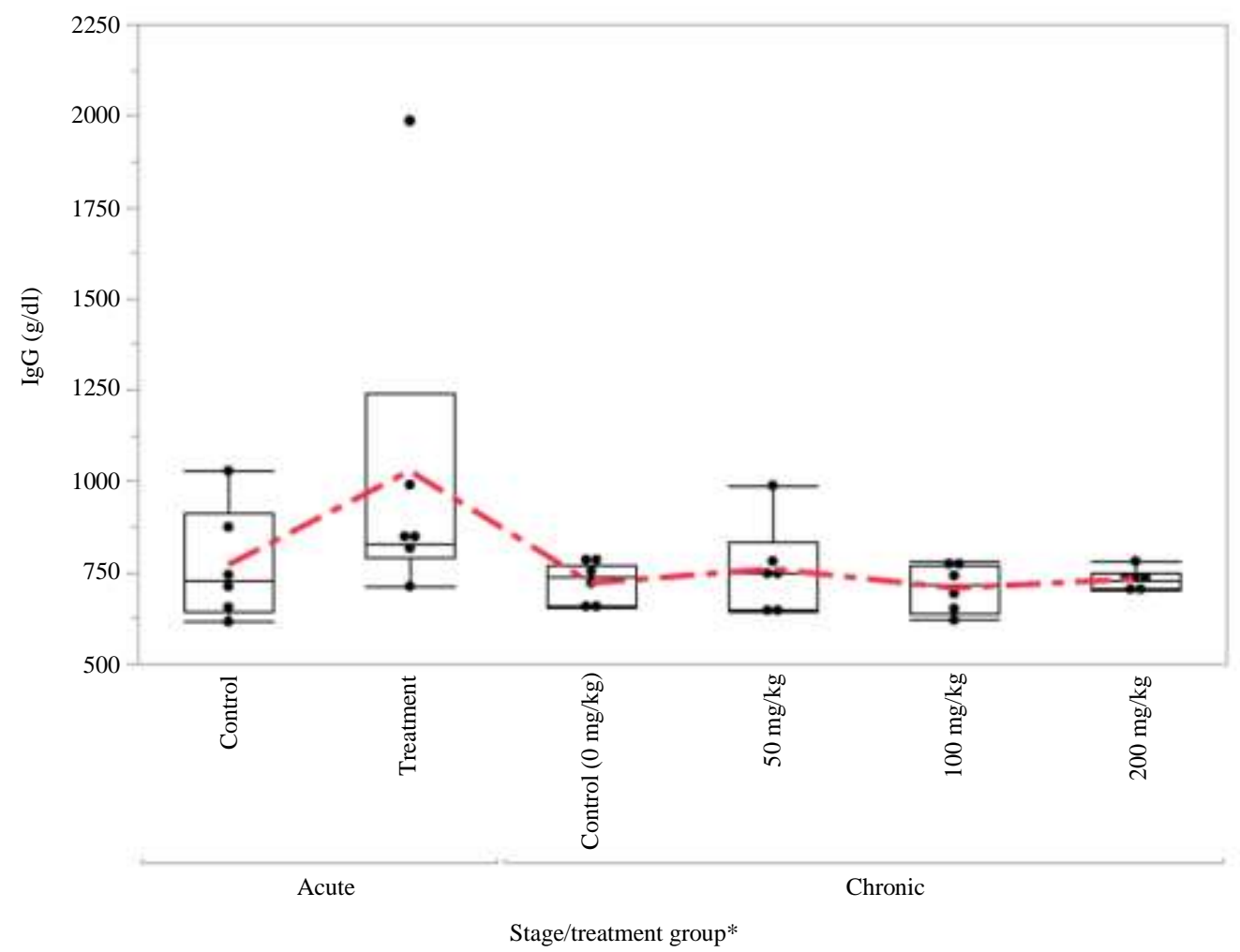

Fig. 8: Box plot of serum IgG concentrations in the control and treatment groups during acute and chronic intoxications

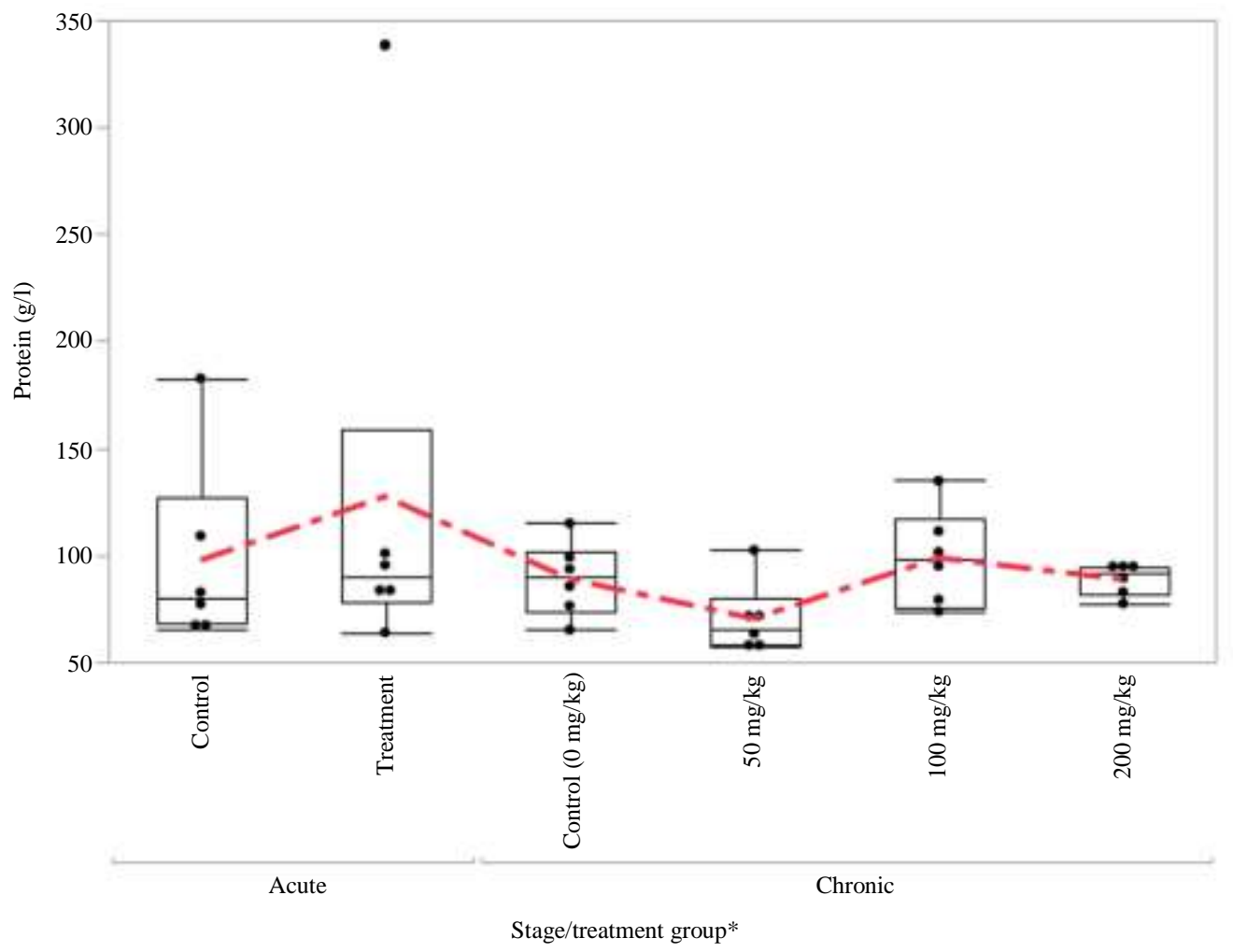

Fig. 9: Box plot of serum total protein concentrations in the control and treatment groups during acute and chronic intoxications 


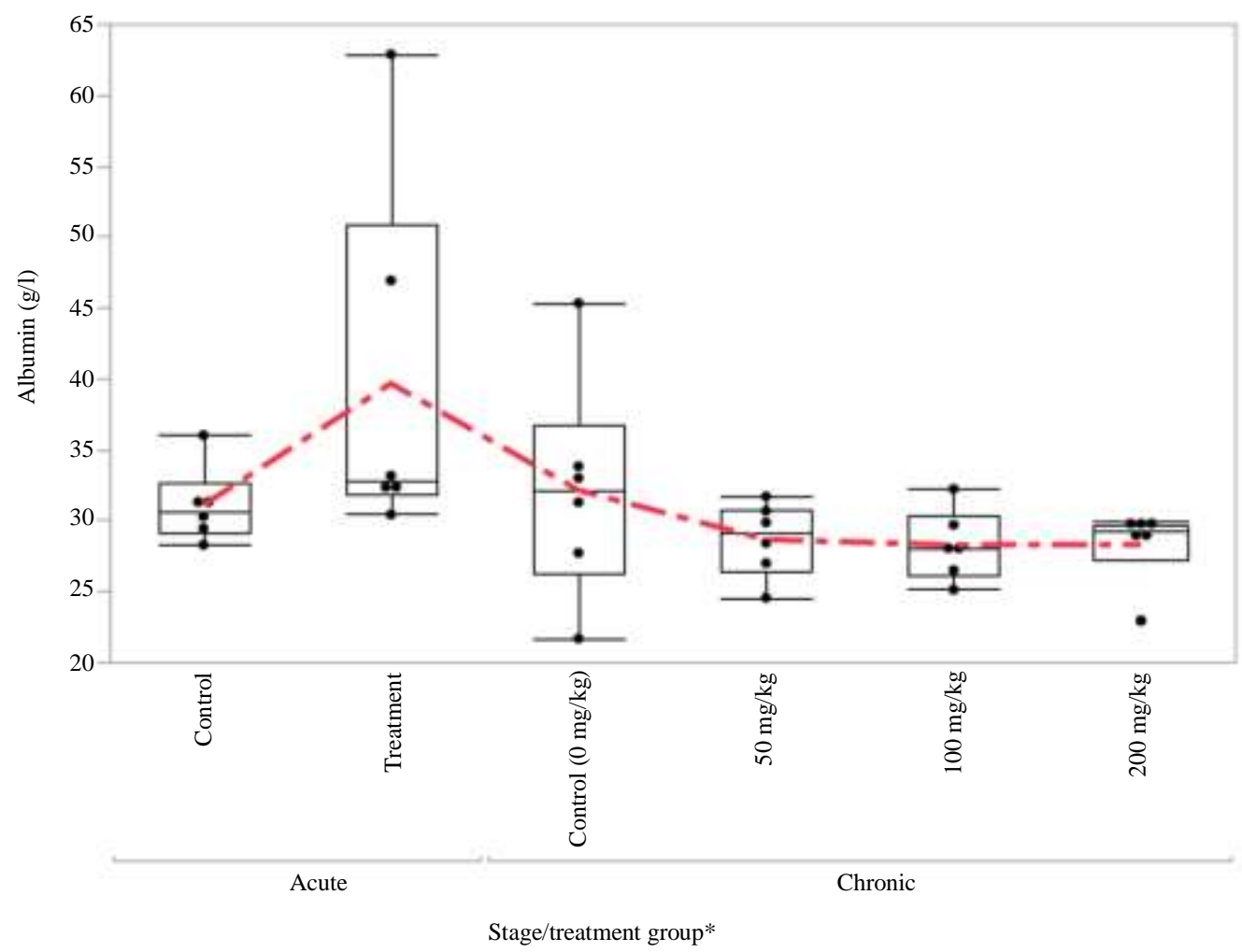

Fig. 10: Box plot of serum albumin concentrations in the control and treatment groups during acute and chronic intoxications

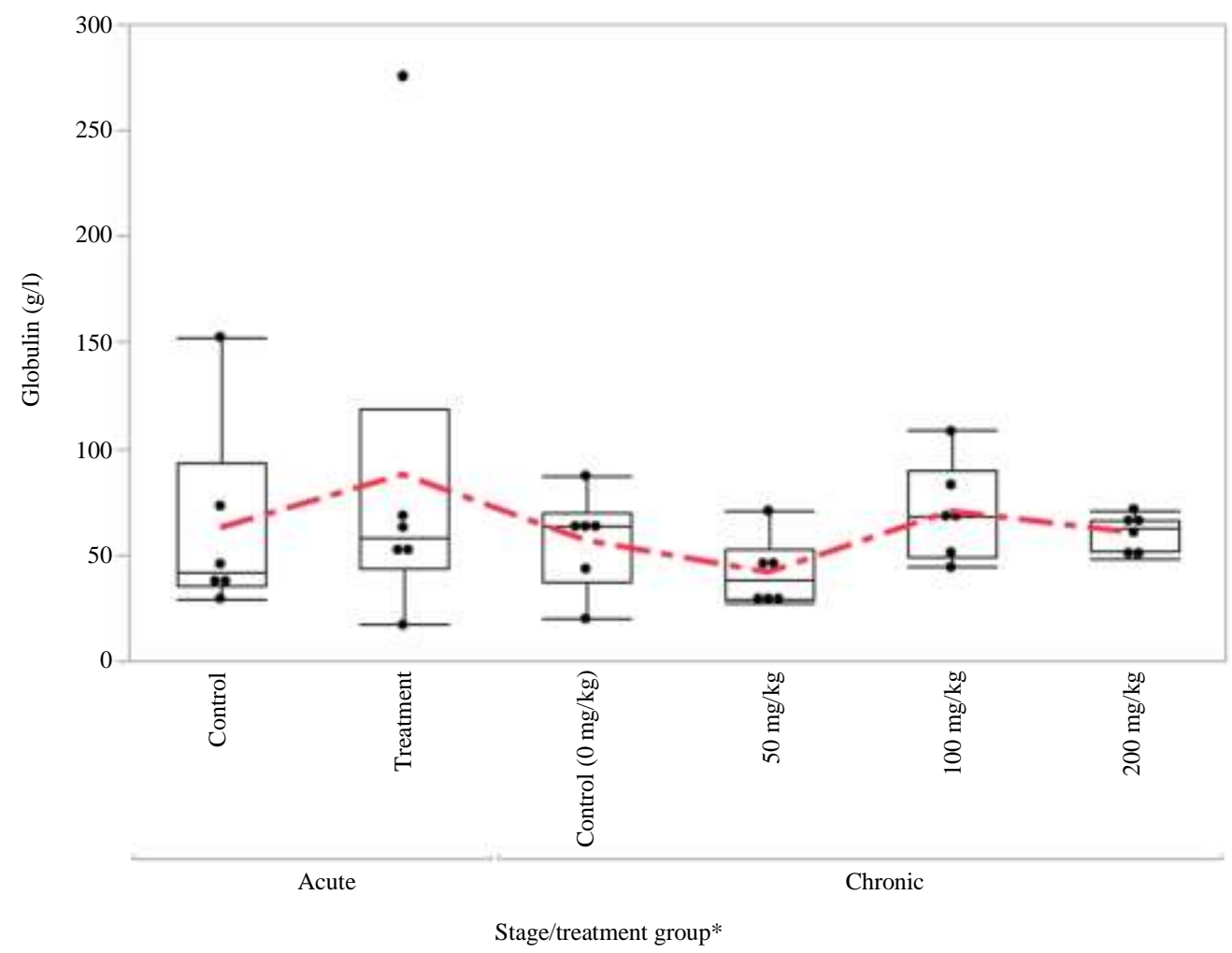

Fig. 11: Box plot of serum globulin concentrations in the control and treatment groups during acute and chronic intoxications 
Table 1: Comparisons of immunological parameters in the acute stage between the treatment and the control groups

\begin{tabular}{|c|c|c|c|c|}
\hline \multirow[b]{2}{*}{ Parameter } & \multicolumn{2}{|l|}{ Experimental group $(\mathrm{N}=12)$} & \multicolumn{2}{|c|}{ Test statistics } \\
\hline & Treatment $(n=6)$ Mean \pm SEM & Control $(n=6)$ Mean \pm SEM & t- Ratio & Prob. $>|t|$ \\
\hline WBC (x 1012/L) & $13.63 \pm 1.15$ & $10.35 \pm 1.63$ & 1.65 & $0.1302 \mathrm{~ns}$ \\
\hline Neutrophils (\%) & $36.17 \pm 3.69$ & $41.33 \pm 4.06$ & -0.94 & $0.3688 \mathrm{~ns}$ \\
\hline Lymphocytes (\%) & $53.00 \pm 3.08$ & $48.67 \pm 3.56$ & 0.92 & $0.3785 \mathrm{~ns}$ \\
\hline Mono $(\%)$ & $7.17 \pm 1.08$ & $7.33 \pm 0.76$ & -0.13 & $0.9019 \mathrm{~ns}$ \\
\hline Eosin $(\%)$ & $3.67 \pm 0.49$ & $2.67 \pm 0.21$ & 1.86 & $0.0924 \mathrm{~ns}$ \\
\hline CD4 (ul) & $8.17 \pm 0.65 \mathrm{a}$ & $4.67 \pm 0.67 b$ & 3.75 & $0.0038 * *$ \\
\hline $\operatorname{IgM}(\mathrm{g} / \mathrm{dl})$ & $896.89 \pm 343.81$ & $538.70 \pm 90.37$ & 1.01 & $0.0374 *$ \\
\hline $\operatorname{IgG}(\mathrm{g} / \mathrm{dl})$ & $1027 \pm 195.16$ & $770.26 \pm 62.95$ & 1.25 & $0.0385 *$ \\
\hline Protein $(g / l)$ & $127.41 \pm 42.50$ & $97.63 \pm 18.13$ & 0.64 & $0.5338 \mathrm{~ns}$ \\
\hline Albumin $(\mathrm{g} / \mathrm{l})$ & $39.65 \pm 5.25$ & $31.07 \pm 1.10$ & 1.60 & $0.1410 \mathrm{~ns}$ \\
\hline Globulin $(\mathrm{g} / \mathrm{l})$ & $87.76 \pm 38.23$ & $62.69 \pm 19.01$ & 0.59 & $0.5701 \mathrm{~ns}$ \\
\hline
\end{tabular}

Legend

SEM: Standard error of mean;

+Experimental Group: Treatment group-Rats received a lethal dose of Tramadol (Acute Stage), Control group - Rats without Tramadol

Within parameters, means \pm SEM with different superscripts are significantly different at $p<0.05$.

Significance Level: $*=p<0.05 ; * *=P<0.01 ; * * *=p<0.0001 ;$ ns $=$ Not Significant $(p>0.05)$.

Table 2: Comparisons of immunological parameters in the experimental treatment during the chronic stage

\begin{tabular}{|c|c|c|c|c|c|c|}
\hline \multirow[b]{3}{*}{ Parameter } & \multicolumn{4}{|c|}{ Experimental treatment $(\mathrm{N}=24)$} & \multirow{2}{*}{\multicolumn{2}{|c|}{ Test statistics }} \\
\hline & $0 \mathrm{mg} / \mathrm{kg}$ (Control) & $50 \mathrm{mg} / \mathrm{kg}$ & $100 \mathrm{mg} / \mathrm{kg}$ & $200 \mathrm{mg} / \mathrm{kg}$ & & \\
\hline & Mean \pm SEM & Mean \pm SEM & Mean \pm SEM & Mean \pm SEM & F-Ratio & Prob. $>\mathrm{F}$ \\
\hline $\mathrm{WBC}\left(\times 10^{12} / \mathrm{L}\right)$ & $7.48 \pm 1.44$ & $6.82 \pm 2.12$ & $12.92 \pm 2.47$ & $10.22 \pm 0.65$ & 2.383 & $0.0998 \mathrm{~ns}$ \\
\hline Neutrophils (\%) & $15.00 \pm 1.53$ & $15.33 \pm 1.15$ & $15.83 \pm 0.98$ & $19.50 \pm 2.72$ & 1.449 & $0.2585 \mathrm{~ns}$ \\
\hline Lymphocytes (\%) & $73.67 \pm 2.39$ & $74.50 \pm 2.08$ & $74.33 \pm 1.41$ & $69.33 \pm 2.80$ & 1.203 & $0.3342 \mathrm{~ns}$ \\
\hline Mono (\%) & $8.67 \pm 0.88$ & $6.50 \pm 1.09$ & $6.00 \pm 0.93$ & $6.83 \pm 0.70$ & 1.628 & $0.2146 \mathrm{~ns}$ \\
\hline Eosin $(\%)$ & $4.33 \pm 0.42$ & $3.67 \pm 0.33$ & $3.67 \pm 0.21$ & $4.00 \pm 0.37$ & 0.873 & $0.4715 \mathrm{~ns}$ \\
\hline CD4 (ul) & $5.00 \pm 0.58^{\mathrm{a}}$ & $9.00 \pm 1.32^{\mathrm{b}}$ & $9.00 \pm 1.88^{\mathrm{b}}$ & $5.33 \pm 0.84^{\mathrm{a}}$ & 3.116 & $0.0492 *$ \\
\hline $\operatorname{IgM}(\mathrm{g} / \mathrm{dl})$ & $565.48 \pm 102.24$ & $473.35 \pm 44.66$ & $487.03 \pm 58.25$ & $373.10 \pm 15.19$ & 1.553 & $0.2320 \mathrm{~ns}$ \\
\hline $\operatorname{IgG}(\mathrm{g} / \mathrm{dl})$ & $720.55 \pm 21.38$ & $759.22 \pm 51.22$ & $707.07 \pm 27.09$ & $731.51 \pm 11.52$ & 0.497 & $0.6887 \mathrm{~ns}$ \\
\hline Protein $(g / l)$ & $88.90 \pm 7.09$ & $70.39 \pm 6.91$ & $98.78 \pm 9.32$ & $88.70 \pm 2.92$ & 2.899 & $0.0604 \mathrm{~ns}$ \\
\hline Albumin (g/l) & $32.12 \pm 3.20$ & $28.64 \pm 1.06$ & $28.26 \pm 1.02$ & $28.27 \pm 1.08$ & 1.034 & $0.3991 \mathrm{~ns}$ \\
\hline Globulin (g/l) & $56.78 \pm 9.31$ & $41.74 \pm 6.70$ & $70.52 \pm 9.43$ & $60.36 \pm 3.41$ & 2.449 & $0.0934 \mathrm{~ns}$ \\
\hline
\end{tabular}

Legend

SEM: Standard error of mean;

+ Within parameters, means \pm SEM with different superscripts are significantly different at $p<0.05$.

Number per treatment, $\mathrm{n}=6$;

Significance Level: $*=p<0.05 ; * * *=p<0.0001 ; n s=$ Not Significant $(p>0.05)$.

Table 3: Pairwise correlations of immunological parameters following lethal dose of tramadol (Acute Stage) in rats

\begin{tabular}{|c|c|c|c|c|c|}
\hline \multirow[b]{3}{*}{$\underline{\text { Parameters }}$} & \multirow[b]{3}{*}{ By parameter } & \multicolumn{4}{|l|}{ Acute stage } \\
\hline & & \multicolumn{2}{|l|}{ Treatment } & \multicolumn{2}{|l|}{ Control } \\
\hline & & Correlation & $\mathrm{P}$-value & Correlation & $\mathrm{P}$-value \\
\hline$\overline{\text { NEUT }(\%)}$ & $\mathrm{WBC}\left(\times 10^{\wedge} 12 / \mathrm{L}\right)$ & -0.833 & $0.0397 *$ & -0.199 & 0.7058 \\
\hline $\operatorname{LYMP}(\%)$ & $\mathrm{WBC}\left(\times 10^{\wedge} 12 / \mathrm{L}\right)$ & 0.926 & $0.0080 * *$ & 0.126 & 0.8125 \\
\hline $\operatorname{LYMP}(\%)$ & NEUT (\%) & -0.957 & $0.0028 * *$ & -0.986 & $0.0003 * * *$ \\
\hline $\operatorname{IgG}(\mathrm{g} / \mathrm{dl})$ & $\mathrm{WBC}\left(\times 10^{\wedge} 12 / \mathrm{L}\right)$ & 0.158 & 0.7651 & -0.836 & $0.0381 *$ \\
\hline $\operatorname{IgG}(\mathrm{g} / \mathrm{dl})$ & $\operatorname{EOSIN}(\%)$ & -0.353 & 0.4921 & -0.907 & $0.0125^{* *}$ \\
\hline $\operatorname{IgG}(\mathrm{g} / \mathrm{dl})$ & $\operatorname{IgM}(\mathrm{g} / \mathrm{dl})$ & 0.983 & $0.0004 * * *$ & -0.006 & 0.9906 \\
\hline Protein $(g / 1)$ & $\operatorname{IgM}(\mathrm{g} / \mathrm{dl})$ & 0.992 & $<0.0001 * * * *$ & 0.426 & 0.3998 \\
\hline Protein (g/l) & $\operatorname{IgG}(\mathrm{g} / \mathrm{dl})$ & 0.994 & $<0.0001 * * * *$ & 0.088 & 0.8679 \\
\hline Albumin (g/l) & $\operatorname{IgG}(\mathrm{g} / \mathrm{dl})$ & 0.814 & $0.0486^{*}$ & -0.747 & 0.0878 \\
\hline Albumin $(\mathrm{g} / \mathrm{l})$ & Protein $(\mathrm{g} / \mathrm{l})$ & 0.834 & $0.0392 *$ & 0.133 & 0.8011 \\
\hline Globulin (g/l) & $\operatorname{IgM}(\mathrm{g} / \mathrm{dl})$ & 0.992 & $<0.0001 * * * *$ & 0.279 & 0.5921 \\
\hline Globulin (g/l) & $\operatorname{IgG}(\mathrm{g} / \mathrm{dl})$ & 0.993 & $<0.0001 * * * *$ & 0.165 & 0.7542 \\
\hline Globulin $(\mathrm{g} / \mathrm{l})$ & Protein $(\mathrm{g} / \mathrm{l})$ & 0.997 & $<0.0001 * * * *$ & 0.981 & $0.0005^{* * *}$ \\
\hline
\end{tabular}

Significance Level: $*=\mathrm{p}<0.05 ; * *=\mathrm{p}<0.01 ; * * *=\mathrm{p}<0.001 ; * * * *=\mathrm{p}<0.0001$ 
Table 4: Pairwise correlations of immunological parameters following experimental treatment with tramadol in rats (Chronic Stage)

\begin{tabular}{|c|c|c|c|c|c|c|c|c|c|}
\hline \multirow[b]{3}{*}{ Parameter } & \multirow[b]{3}{*}{ By parameter } & \multicolumn{8}{|c|}{ Experimental group } \\
\hline & & \multicolumn{2}{|c|}{$0 \mathrm{mg} / \mathrm{kg}$ (Control) } & \multicolumn{2}{|l|}{$50 \mathrm{mg} / \mathrm{kg}$} & \multicolumn{2}{|l|}{$100 \mathrm{mg} / \mathrm{kg}$} & \multicolumn{2}{|l|}{$200 \mathrm{mg} / \mathrm{kg}$} \\
\hline & & Correlation & $\mathrm{P}$-value & Correlation & P-value & Correlation & P-value & Correlation & $\mathrm{P}$-value \\
\hline NEUT (\%) & WBC $\left(\times 10^{12} / \mathrm{L}\right)$ & -0.276 & 0.5960 & -0.864 & $0.0266^{*}$ & -0.358 & 0.4859 & -0.200 & 0.7043 \\
\hline LYMP (\%) & $\mathrm{WBC}\left(\times 10^{12} / \mathrm{L}\right)$ & 0.273 & 0.6008 & 0.863 & $0.0268^{*}$ & 0.363 & 0.47 & 0.337 & 0.5130 \\
\hline LYMP (\%) & NEUT (\%) & -0.922 & $0.0088^{* *}$ & -0.841 & $0.0360^{*}$ & -0.717 & 0.1086 & -0.977 & $0.0008 * * *$ \\
\hline MONO (\%) & $\mathrm{WBC}\left(\times 10^{\wedge} 12 / \mathrm{L}\right)$ & -0.817 & $0.0471^{*}$ & -0.775 & 0.0703 & -0.107 & 0.8395 & -0.789 & 0.0620 \\
\hline MONO (\%) & LYMP $(\%)$ & -0.074 & 0.8895 & -0.922 & $0.0089^{*} *$ & -0.611 & 0.1975 & -0.553 & 0.2552 \\
\hline CD4 (ul) & EOSIN (\%) & -0.822 & $0.0449 *$ & -0.304 & 0.5583 & 0.252 & 0.6295 & 0.325 & 0.5300 \\
\hline $\operatorname{IgM}(\mathrm{g} / \mathrm{dl})$ & $\mathrm{WBC}\left(\times 10^{\wedge} 12 / \mathrm{L}\right)$ & -0.250 & 0.6332 & 0.326 & 0.5288 & 0.711 & 0.1135 & 0.848 & $0.0328^{*}$ \\
\hline $\operatorname{IgM}(\mathrm{g} / \mathrm{dl})$ & NEUT (\%) & -0.849 & $0.0325^{*}$ & -0.074 & 0.8894 & -0.354 & 0.4915 & -0.459 & 0.3600 \\
\hline $\operatorname{IgM}(\mathrm{g} / \mathrm{dl})$ & LYMP (\%) & 0.831 & $0.0406^{*}$ & 0.272 & 0.6021 & 0.454 & 0.3658 & 0.556 & 0.2517 \\
\hline $\operatorname{IgM}(\mathrm{g} / \mathrm{dl})$ & MONO (\%) & 0.308 & 0.5519 & -0.329 & 0.5249 & -0.145 & 0.7837 & -0.870 & $0.0243^{*}$ \\
\hline $\mathrm{IgG}(\mathrm{g} / \mathrm{dl})$ & NEUT $(\%)$ & -0.871 & $0.0238^{*}$ & -0.103 & 0.8462 & 0.583 & 0.2249 & -0.362 & 0.4804 \\
\hline $\operatorname{IgG}(\mathrm{g} / \mathrm{dl})$ & CD4 (ul) & -0.602 & 0.2059 & -0.526 & 0.2834 & -0.870 & $0.0242 *$ & -0.794 & 0.0593 \\
\hline $\operatorname{IgG}(\mathrm{g} / \mathrm{dl})$ & $\operatorname{IgM}(\mathrm{g} / \mathrm{dl})$ & 0.905 & $0.0132 * *$ & 0.402 & 0.4295 & -0.120 & 0.8201 & -0.151 & 0.7747 \\
\hline Protein (g/l) & MONO (\%) & 0.520 & 0.2905 & -0.117 & 0.8251 & 0.061 & 0.9091 & -0.830 & $0.0408^{*}$ \\
\hline Protein $(\mathrm{g} / \mathrm{l})$ & $\operatorname{EOSIN}(\%)$ & 0.526 & 0.2840 & -0.097 & 0.8557 & -0.823 & $0.0443 *$ & -0.214 & 0.6836 \\
\hline Albumin (g/l) & $\mathrm{WBC}\left(\times 10^{\wedge} 12 / \mathrm{L}\right)$ & 0.830 & $0.0409 *$ & -0.246 & 0.6382 & -0.385 & 0.4510 & -0.511 & 0.3001 \\
\hline Albumin (g/l) & NEUT $(\%)$ & -0.427 & 0.3980 & 0.424 & 0.4018 & 0.737 & 0.0948 & 0.883 & $0.0199^{*}$ \\
\hline Albumin (g/l) & $\operatorname{LYMP}(\%)$ & 0.544 & 0.2649 & -0.036 & 0.9467 & -0.283 & 0.5868 & -0.938 & $0.0056^{* *}$ \\
\hline Globulin (g/1) & $\operatorname{WBC}\left(\times 10^{\wedge} 12 / \mathrm{L}\right)$ & -0.795 & 0.0585 & 0.154 & 0.7706 & -0.249 & 0.6344 & 0.842 & $0.0356^{*}$ \\
\hline Globulin $(\mathrm{g} / \mathrm{l})$ & MONO (\%) & 0.575 & 0.2322 & -0.098 & 0.8530 & 0.109 & 0.8364 & -0.945 & $0.0044 * *$ \\
\hline Globulin (g/l) & EOSIN (\%) & 0.321 & 0.5354 & 0.021 & 0.9682 & -0.842 & $0.0353 *$ & -0.189 & 0.7206 \\
\hline Globulin (g/l) & $\operatorname{IgM}(\mathrm{g} / \mathrm{dl})$ & 0.122 & 0.8177 & 0.326 & 0.5285 & 0.241 & 0.6456 & 0.830 & $0.0409 *$ \\
\hline Globulin (g/l) & Protein $(\mathrm{g} / \mathrm{l})$ & 0.960 & $0.0024 * *$ & 0.988 & $0.0002 * * *$ & 0.994 & $<.0001 * * * *$ & 0.960 & $0.0023 * *$ \\
\hline
\end{tabular}

Significance level: $*=\mathrm{p}<0.05 ; * *=\mathrm{p}<0.01 ; * * *=\mathrm{p}<0.001 ; * * * *=\mathrm{p}<0.0001$

Some of the parameters as established in the tables exhibited either negative or positive correlations. Figure 1 and 3 show a mean increase in total white blood cells and lymphocyte counts in the treatments when compared to the controls in both the acute and chronic phases, whereas a decrease in monocyte count (Fig. 4). Figure 2 exhibited a mean decrease strictly in the acute phase of the study. Eosinophil and CD4 counts increased in the acute phase, whereas exhibited a decrease in the chronic phase respectively (Figs. 5 and 6). Serum IgM, IgG, total protein, albumin and globulin exhibited an increase in concentrations in the acute phase, but the direct opposite in the chronic phase when treatments compared to the paired controls respectively (Figs. 7-11).

\section{Discussion}

Tramadol abuse is on the increase in Nigeria due to its rapidity in creating euphoria and pain relief. The acute and long-term side effects are still controversial with swerving opinions. This study was therefore undertaking to critically evaluate the immunological status emanating from acute and/or chronic tramadol intoxication.

The study revealed a significant increase in concentrations of CD4, serum IgG and IgM in the acute tramadol intoxicated rats when compared to the controls. Correlational analysis also exhibited both positive and negative correlations between some of the immune cells, immunological and ancillary. The significant difference and correlational relationships observed amongst the immune cells, immunological and ancillary biochemical parameters have given credence to the potencies of tramadol in creating imbalances in the immunological milieu of the body. The increase could be attributed to stimulation of the immune system resulting from foreign bodies' assault. Immune cells and signals are known to be released whenever the body systems are threatened by foreign bodies (Kaufmann et al., 2003; Moore and Keruly, 2007). The leap observed is indicative of the usefulness of utilizing immunological signals in advancing investigation into tramadol intoxication death.

Also, the increase observed could be therapeutically useful in instigating the production and release of immune cells and signals that could aid in the destruction of germs and other toxic substances deleterious to the body. This could be of critical use in situations of compromised immune system resulting from microbial or toxicological influences. This narrative is supported by a study conducted by (Zhou et al., 2013). They posited that tramadol can improve cellular immune function in perioperative gastric cancer patients by impeding the depletion of T-lymphocytes subsets and Natural Killer (NK) cells. On the contrary, a study by (Edelman et al., 2016) on HIV/AIDS subjects showed no significant effect of tramadol on the CD4 count.

The findings of the effect of chronic tramadol intoxication on immunological cells and signals established a significant elevation of CD4 count in 50 and $100 \mathrm{mg} / \mathrm{kg}$ and a consequential fall in $200 \mathrm{mg} / \mathrm{kg}$ regime when compared to the controls. The correlational analysis 
also showed both negative and positive correlations between immune cells, immunological and biochemical parameters of the various categories of the chronic intoxications. The increase in CD4 count could be ascribed to the reason advanced for the acute intoxication. The later fall as observed could be attributed to damping effect of the immune stimulation due to increase in dosage and excessive exposures.

The findings resulting from chronic tramadol intoxication is of great importance especially amongst patients with depressed immune system. Tramadol exposure has shown to stimulate the production and subsequent release of CD4 cells into the blood stream. Conditions such as Acquired Immune Deficiency Syndrome (AIDS), cancer and organ failures are known depressants of the immune system. These conditions could benefit from the use of tramadol in enhancing the immune system. The significant increase in CD4 count observed in the chronic phase is in agreement with that of the acute. This has further reaffirmed the possible competence of tramadol in enhancing the immunological capacity of the body. The findings of this study concur with that of (Liu et al., 2006).

The Pearson correlational analysis between the parameters utilized in the acute phase revealed a significant correlation between lymphocyte and neutrophil counts, IgG and $\mathrm{WBC}$, IgG and eosinophil, IgG and IgM, total protein and $\mathrm{Hb}$, protein and $\mathrm{IgM}$, protein and $\mathrm{IgG}$. Others were albumin and $\mathrm{IgG}$, albumin and total protein, globulin and IgM and globulin and IgG.

Similarly, correlations were also observed between lymphocyte and neutrophil, IgG and WBC, IgG and eosinophil, IgG and IgM, total protein and $\mathrm{Hb}$, protein and $\mathrm{IgM}$, protein and IgG, globulin and IgM and globulin and IgG. All the listed parameters are associated with immunity and immunological status of the body. Both are driven purposely to protect the body from internal and external aggressions. The presence of pathogens or toxins has the preponderances of stimulating the production of immune cells and substance. In normal circumstances, these cells and substances are not significantly distorted. It is expected that an alteration of one of the parameter could have a concomitant effect on others. Based on the findings of the correlation, it could be inferred that tramadol has a direct effect on the immune system that could be of therapeutic value if appropriately administered optimally or could be deleterious if administered excessively.

The study utilized animal model in coming about its narrative, a need for a human trial is apt. This will in no measure consolidate on the direction of argument of this study. The immune excitement resulting from tramadol intoxication or abuse ought to be investigated further to know whether it is beneficial or deleterious.

\section{Limitation of the Study}

Funding was the major limitation. It restricted the scope of the study to immune cells and molecules. The inclusion of inflammatory markers and molecules would have expanded the perspective of the study better.

\section{Conclusion}

The present study demonstrated that, tramadol intoxication and abuse has the preponderances of compromising the immune apparatuses of the body. The acute study involving the use of high concentration of tramadol that led to the death of the study animal showed significant increase concentrations of CD4, IgG and IgM. This could be of adjunct use in discriminating death due to tramadol overdose. The chronic intoxication also implicated an elevation in serum CD4 count which could be of use in stimulating the immune system in situation of immune depression. However, the posture of the study has shown that indiscriminate and prolonged use of tramadol which may lead to accumulated damage and possibly mortality.

\section{Acknowledgement}

Special appreciation the staff of the Department of Medical Laboratory Science and Pharmacology and Toxicology of the Niger Delta University, Wilberforce Island, Bayelsa State, Nigeria. Also special appreciation, to the staff of the Federal Medical Centre Yenagoa and the Niger Delta University Teaching Hospital Okolobiri, Bayelsa State.

\section{Author's Contributions}

Loveday Udu Zebedee and Zaccheus Awortu Jeremiah: Did the experimental and literature review aspect of the work.

Nyebuchi Jonathan and Eni-Yimini Solomon Agoro: Did the collation of results and the statistical analysis.

\section{Ethics Approval}

Approval for the study was done by the Ethics Committee of the Bayelsa State Ministry of Health Bayelsa State, Nigeria.

\section{References}

Agoro, E. S., Ogbotobo, R. I., Ombor, J., Thomas, C., Mac'odo, Y., \& Wankasi, M. M. (2012). Relationships between Serum Globulins, Albumin/Globulin Ratio and C-Reactive Proteins in Pregnancy Trimesters. Journal of Medical Laboratory Science, 21(1), 49-57. https://www.ajol.info/index.php/jmls/article/view/12 0505 
Agoro, E. S., Wankasi, M. M., Zebedee, U. L., \& Agoro, E. Y. (2019). The Effects of Chronic Carbon Monoxide Intoxication on Some Haematological Parameters and Films in Rabbits. Advanced Journal of Toxicology: Current Research, 3(1), 1-5. https://www.researchgate.net/publication/33090124

3_The_Effects_of_Chronic_Carbon_Monoxide_Into xication_on_Some_Haematological_Parameters_an d_Films_in_Rabbits

Alagoa, E. J. (Ed.). (1999). The land and people of Bayelsa state: Central Niger Delta. Onyoma Research Publications.

Alberts, B., Johnson, A., Lewis, M., Raff, M., Roberts, K., \& Walter, P. (2002). Leukocyte also known as macrophages functions and percentage breakdown. Molecular Biology of the Cell (4th ed.). New York: Garland Science.

BBC News. (2018). Nigeria's tramadol crisis: the drug fueling death, depair and Boko Haram. https://www.bbc.com/news/world-africa-44306086

Capolunghi, F., Rosado, M. M., Sinibaldi, M., Aranburu, A., \& Carsetti, R. (2013). Why do we need IgM memory B cells?. Immunology Letters, 152(2), 114-120. https://doi.org/10.1016/j.imlet.2013.04.007

Chikezie, U. E., \& Ebuenyi, I. D. (2019). Tramadol misuse in the Niger Delta; A review of cases presenting within a year. Journal of Substance Use, 24(5), 487-491. https://doi.org/10.1080/14659891.2019.1604842

Ciccarelli, F., De Martinis, M., \& Ginaldi, L. (2014). An update on autoinflammatory diseases. Current Medicinal Chemistry, 21(3), 261-269. https://doi.org/10.2174/09298673113206660303

Cox, L., Williams, B., Sicherer, S., Oppenheimer, J., Sher, L., Hamilton, R., \& Golden, D. (2008). Pearls and pitfalls of allergy diagnostic testing: report from the American college of allergy, asthma and immunology/American academy of allergy, asthma and immunology specific IgE test task force. Annals of Allergy, Asthma \& Immunology, 101(6), 580-592. https://doi.org/10.1016/S1081-1206(10)60220-7

Edelman, E. J., Gordon, K. S., Tate, J. P., Becker, W. C., Bryant, K., Crothers, K., ... \& Fiellin, D. A. (2016). The impact of prescribed opioids on CD 4 cell count recovery among $\mathrm{HIV}$-infected patients newly initiating antiretroviral therapy. HIV Medicine, 17(10), 728-739. https://doi.org/10.1111/hiv.12377

Grond, S., \& Sablotzki, A. (2004). Clinical pharmacology of tramadol. Clinical Pharmacokinetics, 43(13), 879-923. https://doi.org/10.2165/00003088-200443130-00004
Hamad, A. A., Torad, F. A., Thabet, N. S., \& Gadallah, S. M. (2016). Effect of Tramadol Versus Fentanyl on Some Hematological and Serum Biochemical Parameters in Dogs. Alexandria Journal for Veterinary Sciences, 50(1), 122-129. https://doi.org/10.5455/ajvs.231096

Hubrecht, R. C., \& Kirkwood, J. (Eds.). (2010). The UFAW handbook on the care and management of laboratory and other research animals. John Wiley \& Sons.

Ibrahim, A. W., Yerima, M. M., Pindar, S. K., Onyencho, V. C., Ahmed, H. K., Machina, B. K., ... \& Wakil, M. A. (2017). Tramadol abuse among patients attending an addiction clinic in North-Eastern Nigeria: outcome of a four year retrospective study. Advances in Psychology and Neuroscience, 2(1-2), 31-37. https://doi.org/10.11648/j.apn.s.2017020201.16

Junqueira, L. C., \& Jose, C. (2003). Basic Histology. McGraw-Hill.

Kaufmann, G. R., Perrin, L., Pantaleo, G., Opravil, M., Furrer, H., Telenti, A., ... \& Battegay, M. (2003). CD4 T-lymphocyte recovery in individuals with advanced HIV-1 infection receiving potent antiretroviral therapy for 4 years: the Swiss HIV Cohort Study. Archives of Internal Medicine, 163(18), 2187-2195. https://doi.org/10.1001/archinte.163.18.2187

Lakos, G., Soós, L., Fekete, A., Szabo, Z., Zeher, M., Horvath, I. F., ... \& Szekanecz, Z. (2008). Anti-cyclic citrullinated peptide antibody isotypes in rheumatoid arthritis: association with disease duration, rheumatoid factor production and the presence of shared epitope. Clinical and Experimental Rheumatology, 26(2), 253. file://C:/Users/WindowS\%2010/Downloads/articl e.pdf

Liu, Z., Gao, F., \& Tian, Y. (2006). Effects of morphine, fentanyl and tramadol on human immune response. Journal of Huazhong University of Science and Technology, 26(4), 478-481. https://doi.org/10.1007/s11596-006-0427-5

Michael, L. B., Edward, P. F., \& Larry, E. S. (1991). Clinical chemistry: principles, procedures, correlations. Philadelphia: Lippincott Williams \& Wilkins, ISBN-10: 0397548249.

Moore, R. D., \& Keruly, J. C. (2007). CD4+ cell count 6 years after commencement of highly active antiretroviral therapy in persons with sustained virologic suppression. Clinical Infectious Diseases, 44(3), 441-446. https://doi.org/10.1086/510746

Ness, R. D. (1999). Clinical pathology and sample collection of exotic small mammals. Veterinary Clinics of North America: Exotic Animal Practice, 2(3), 591-620. https://doi.org/10.1016/S10949194(17)30112-3 
Randall, C., \& Crane, J. (2014). Tramadol deaths in Northern Ireland: A review of cases from 1996 to 2012. Journal of Forensic and Legal Medicine, 23, 32-36. https://doi.org/10.1016/j.jflm.2014.01.006

Rossi, S. (2013). Australian medicines handbook 2013. Adelaide: Australian Medicines Handbook Pty Ltd.

Sacerdote, P., Bianchi, M., Gaspani, L., Manfredi, B., Maucione, A., Terno, G., ... \& Panerai, A. E. (2000). The effects of tramadol and morphine on immune responses and pain after surgery in cancer patients. Anesthesia \& Analgesia, 90(6), 1411-1414. https://doi.org/10.1097/00000539-200006000-00028
Sacerdote, P., Bianchi, M., Manfredi, B., \& Panerai, A. E. (1997). Effects of tramadol on immune responses and nociceptive thresholds in mice. Pain, 72(3), 325-330 https://doi.org/10.1016/S0304-3959(97)00055-9

Williams, N., \& O'Connell, P. R. (Eds.). (2008). Bailey \& Love's short practice of surgery. CRC press.

Zhou, L. W., Ding, H. L., Li, M. Q., Jin, S., Wang, X. S., \& Ji, L. J. (2013). Effect of tramadol on perioperative immune function in patients undergoing gastric cancer surgeries. Anesthesia, Essays and Researches, 7(1), 54. https://doi.org/10.4103/0259-1162.113992 